\title{
A Genre-Based Analysis on Discussion Section of Research Articles in Indonesian Written by Indonesian Speakers
}

\author{
Safnil Arsyad (Corresponding author) \\ English Study Program of Languages and Arts Department \\ Faculty of Education of University of Bengkulu \\ PO Box 38371A, Bengkulu, Indonesia \\ Tel: 62-073-621-186_E-mail: safnil@yahoo.com
}

Received: May 29, 2013 Accepted: July 3, 2013 Published: August 25, 2013

doi:10.5296/ijl.v5i4.3773 URL: http://dx.doi.org/10.5296/ijl.v5i4.3773

\begin{abstract}
This study examines the genre of research article (RA) discussion section written in Indonesian by Indonesian writer aiming at exploring how Indonesian writers discuss their research findings in their RAs. The corpus for this study consists of 47 selected RAs published mainly in university-based journals in Indonesia from social science and humanity disciplines. Swales' eight-move structure (EMS) model of discussion section of RAs was employed for the data analysis. The results show that the EMS model is effective to use to analyze the move structure of the discussion section of Indonesian RAs; there is no significant difference between the move structures in the Indonesian RAs between different fields of discipline. The most noticeable differences occur in terms of the absence of Move 4 (reference to previous research findings) in the majority of the Indonesian RAs and the difference between the RAs in the same discipline in terms of the number of moves found. The difference in research practice and RA writing practice in Indonesia are the most possible cause of the differences in the move structure.
\end{abstract}

Keywords: Discussion section, Research articles, Communicative purpose or move, Genre-based study, Academic discourse 


\section{Introduction}

Indonesian scholars' contribution in international publication is very small; between 2004 to 2008, for example the Indonesians' international publications were only 2,874 articles while Malaysians' were 8000, Thailands' were 15,000, and Singapores' were more than 30,000 (Ariwibowo, 2008). This means that out of 100 Indonesian scholars only 8 or $8 \%$ of them published internationally in 4 years or only 2 or $2 \%$ of them published in an international journal in one year. According to Wahid (2011), in terms of their contribution to international publication, Indonesian was ranked at the 65 th position compared to Malaysia at the 43rd position and Singapore was at the 32 nd position. This indicates that although Indonesian is much bigger in terms of population and the number of scholars but in terms of their scientific productivity especially about international publication is far below its neighbors such as Malaysia, Singapore and Thailand.

Recently since 2007 and 2008 the research funding for university researchers and university lecturers has increased significantly due to the Indonesian government commitment to improve the quantity and quality of research and academic activities at universities in Indonesia. In addition, the Indonesian government through the directorate general of higher education also provides some funding for Indonesian scholars who will present a paper at an international conference or seminar which leads to a publication in an international journal. However the increase of Indonesian scholars who successfully published his or her RAs in an international journal has not yet significant. In 2010 for example, according to Wahid (2011), the Indonesian position in terms of international publication among Asian countries was still at the 11th position out of 33 countries; this position was only slightly over but can be easily overtaken by Vietnam or Bangladesh in the near future.

Wahid (2011) goes on to point out that, it is not easy to find the exact causes of the under-expectation contribution of Indonesian scholars in the international journal publication because there may be many aspects contributing to this problem. Among other things, Wahid suggests four of them; 1) no significant pressure to Indonesian researchers to publish their research reports in international journals as part of the the research project; 2) no significant difference in terms of credit point given to national and international publication for career developement or salary raise; 3) very limitted funding allocated for Indonesian scholars to present his or her research papers in quality international seminars or conferences leading to an international journal publication; and 4) no significant rewards given to the Indonesian scholars who can successfully publish his or her RAs in international journals. Ofcourse these are only few possible causes contributing to the poor performance of Indonesian scholars in international journal publication although there have been so many studies conducted either as part of qualification processes (of undergraduate, master or doctorate degrees) or research projects done at post-qualification or continuing professional development programs. Other possible causes are the poor ability of the Indonesian scholars to write a RA in a foreign language such as English, the poor ability of the Indonesian scholars to adjust their research papers to the rhetorical structures and styles acceptable in an international journal publication and the poor content quality and value of the RAs produced by the Indonesian researchers. 
One of the most important sections of RAs is the discussion section because in this section writers show the knowledge contribution of their research findings to the available literature. This is also where the writers explain why their research findings are in the ways they are and what they mean (Hess, 2004 and Hagin, 2009). Research article authors must summarize and interpret their research findings, and the place to do so is in the discussion section by commenting on every issue in the research questions (Branson, 2004, Thyer, 2008 and Branson, 2004). However, according to Parkinson (2011:164), most student writers find it very hard to write the RA discussion section because “... it involves complex causal, conditional and purposive argument; this argument guides the reader from acceptance of the relatively uncontroversial data to acceptance of the writer's knowledge claim."

Similar comment on the importance of and the difficulty to write the discussion section of RAs has been put forward by Belcher (2009). Belcher states that,

This [the disussion section of RAs] is the most difficult section to write and yet the most important. How you write this section can determine your article's rejection or acceptance. Even if you have a great data, your article can get rejected for poor or incorect interpretation. Structuring your discussion around your argument will best enable readers to understand the significance of your study for their own research and the field (p:195).

In other words, according to Belcher the quality of discussion section of an RA also determines the quality of the RA itself and therefore, writers must write it carefully conforming to the appropriate discourse structure and style expected by discourse community in a particular discipline.

\section{Literature Review}

\subsection{Common Moves in the Discussion Section of Research Articles}

Swales (1990) suggests that the discussion section of RAs may contain up to eight 'moves' or a segment of text which has a clear communicative purpose set by the writer for the potential readers; these moves are "... background information, statement of results, (un)expected outcome, reference to previous research, explanation, exemplification, deduction and hypothesis and recommendation (pp:172-173)'. However, as Swales claims, out of the eight possible moves in the discussion section of RAs only three moves are compulsary or most commonly found; these are Move 1 (background information), Move 2 (statement of results), and Move 4 (reference to previous research), while the other five moves are rarely used or only found in a particular research discipline or in a RAs using a particular type of research methodology.

Dudley-Evans (1994) suggests a slightly different move structure of discussion section of RA. Instead of eight moves, Dudley-Evans suggests nine possible moves in the discussion section of RAs; these are "...information move, statement of result, finding, (un)expected outcome, reference to previous research, explanation, claim, limitation, and recommendation (p:225)". However, as Dudley-Evans further claims, among the nine moves which are possibly found in the discussion section of RAs, only two move cycle are the most important ones; these are statements of results or findings which are then connected to the findings of previous relevant 
studies or a claim which are then linked with the findings of previous relevant studies.

Although slightly different, the two move structure model suggested by Swales (1990) and Dudley-Evans (1994) are similar in terms of their key cycles or important moves; these are statements of results or findings of the research which are then linked with the findings or previous relevant studies. This is because the discussion section of RA is the opportunity for the writers to review the available information relevant to the research topic and to explain how the current research findings contribute to the available information (Branson, 2004). By doing so, the writers attempt to convince readers that the information obtained from the research has some kind contribution for other scholars who work or are interested in the same research area.

\subsection{Comparative Studies on Research Article Discussion Section}

Several comparative genre studies on discussion section of RAs have been conducted so far, such as by Parkinson (2011), Basturkmen (2012), Salimi and Yazdami (2011), Jalilifar (2011), and Holmes (1997) to name a few. The majority of these studies are comparative in nature either between two or more groups of RAs of different fields of discipline but within the same language or between two or more groups of RAs in different languages but within the same field/s of discipline. The majority of these studies used either Swales' eight-move structure or nine-move structure by Dudley-Evans as a model for analysis.

Holmes (1997) conducted a study on the discussion section of 30 RAs in social sciences consisting of 10 articles in each discipline of history, political science and sociology disciplines. He compared the existence of communicative moves available in the discussion sections in the three groups of RAs. Holmes found that although there are many similarities in terms of the communicative moves in the three groups of articles, there are also differences in which, unlike the ones of political and sociology sciences, the moves in the discussion sections of history RAs was rarely cyclical. Another difference is that, different from the ones in political and sociology sciences, the discussion section of RAs in the discipline of history rarely has reference to the previous research findings or Move 5. According to Holmes, this is because of "... limited development of cummulative research program and the absence of a theoritical concensus in that discipline (p:333)."

Salimi and Yazdami (2011) also conducted a study on move analysis of discussion sections of 80 articles written in English in two different disciplines: 40 articles in Sociolinguistics and 40 articles in Language Testing. Salimi and Yazdami used nine-move structure model of discussion section of RAs suggested by Dudley-Evans (1994) to analyse their data and found that there are no important difference between the two groups of RAs in terms of their macro structure but there is a significant difference on the frequency of absence of important moves in the discussion section of the two groups of RAs. According to Salimi and Yazdami, compared to the ones in Sociolinguistics, the articles in Language Testing are much better in terms of utilizing the important moves in their discussion section. In their conclusion, Salimi and Yazdami stated that writers of RAs in Sociolinguistics did not follow the standard nine moves pattern as suggested by Dudley-Evans as religiously as the writers of Testing articles did. 


\section{Macrothink

Genre-based studies on discussion section of RAs, as reviewed above, have already been conducted on RAs written in English; however, as far as I am concerned there is no study ever conducted on RA discussion section written in Indonesian by Indonesian writers in the disciplines of social sciences and humanities and this is the main motivation for this study. The information on the discourse structure in the discussion section of RAs written in Indonesian and by Indonesian writers is very important for pedagogical purposes. If the differences and similarities are known, it will be clearer and much easier how and what to suggest to the Indonesian students and researchers when they rewrite or convert their RAs in Indonesian into English in order to be published in an English international journal.

This study is an attempt to find out how the discussion section of RAs in the disciplines of social sciences and humanities written in Indonesian by Indonesian writers are rhetorically structured and linguistically characterized as suggested by Swales (1990). The research questions are as folows:

a) What communicative purpose segments or moves are dominantly found in the discussion section of RAs in the disciplines of social science and humanities written in Indonesian by Indonesian writers?

b) Is there any difference between the six groups of the RAs in the disciplines of social sciences, education, economy and management, language and literature, psychology and religious studies in terms move structure in the discussion section of the RAs? and

c) What is the main difference (if any) between the move structure found in the discussion section of Indonesian RAs and the one in English?

\section{Methododology}

\subsection{The Corpus of the Study}

Forty eight RAs in the fields of social sciences and humanities (language and literature, religion, economics, psychology, social and political sciences and education) written in Indonesian by Indonesian writers were selected for analysis. Only one RA (from the most recent volume) was chosen from one Journal to represent the articles published in the journals; this is because it is assumed that all articles published in the journals have gone through a standard editing and reviewing processes following the submission guidelines enforced by the journal editorial boards and therefore all articles published in the journals have conformed to the guidelines. The distribution of the RAs as the object in this study is given in Table 1. 
Table 1. The Distribution of Research Articles in the Corpus of this Study

\begin{tabular}{|l|l|l|l|}
\hline No. & Journal Discipline & Number of RAs & Percentage \\
\hline 1. & Religious study & 4 & $8.5 \%$ \\
\hline 2. & Education & 14 & $29.8 \%$ \\
\hline 3. & Economy and management & 10 & $21.3 \%$ \\
\hline 4. & Language and literature & 6 & $12.8 \%$ \\
\hline 5. & Psychology & 6 & $12.8 \%$ \\
\hline 6. & Social sciences & 7 & $14.9 \%$ \\
\hline Total & 47 & $100 \%$ \\
\hline
\end{tabular}

The number of RAs in each discipline is not equal because the fact that the number of journals available in each discipline published in Indonesia is not equal either. The choice of the disciplines is motivated by the assumption that discourse structure and styles of RAs in social sciences and humanities are more various and nonstandard compared to the one in natural and hard sciences. The list of the 47 articles and the journals from which they were taken is given in the appendix.

\subsection{Genre Analysis Method}

Analysis of the discussion section of the RAs was based on the eight-move structure (EMS) model outlined by Swales (1990:172-173). Swales suggests that the discussion section of RAs may contain up to eight 'moves' or a segment of text which has a clear communicative purpose set by the writer for the readers; these moves are "... background of information, statement of results, (un)expected outcome, reference to previous research, explanation, exemplification, deduction and hypothesis and recommendation". Swales elaborates further that the communicative purposes of each move are as the followings with some modification for practical purposes:

Move 1 (background information) is statement about 'theoritical and technical information' as already addressed earlier in the RA;

Move 2 (statement of results) is the claim made by the writer as the direct answer to their research question;

Move 3 ((un)expected outcome) is statement or comment on whether or not the research results or finding are as they are expected;

Move 4 (reference to previous research) is a rhetorical attempt of writer/s to link the present research finding/s to the available relevant knowledge or information for the purpose of comparison or to support the present findings;

Move 5 (explanation) is the writer's rhetorical attempt to logically convince readers why such unexpected or extraordinary results or findings of the present study occur; 
Move 6 (Exemplification) is only an illustration or samples to strengthen or support the explanation;

Move 7 (deduction and hypothesis) is the writer's claim on the level of interpretation of the research findings to a larger scope of topic or area; and

Move 8 (recommendation) is writer's suggestion on the application or implementation of the research findings in practical ways and/or suggestion for further studies in the same or similar topic.

In this study, following Safnil (2000:82) a communicative unit or move is defined as,

A communicative unit of a text is a clause or a set of clauses or a paragraph which shows a clear indication of a specific identifiable communicative purpose, signaled by linguistic clues or inferred from specific information in the text. The communicative units or moves in a particular text together develop a set of communicative purposes relevant to the genre of the text.

Whether or not a segment in the text, such as a clause(s) or a paragraph(s) can be classified as a Move depends on if or not the segment has a clear different and identifiable communicative purpose or function.

The smallest unit analysis in this study is a clause or a simple sentence because it is unlikely that two or more communicative purposes or moves are addressed in a clause because a clause should have only one topic or subject and one comment or predicate. In addition, the identification of moves in the discussion section of RAs were done by using linguistic and discourse clues; these are formulaic expression, particular lexical items, cohesive markers, by inferring from the information contained in the text, and other kinds of discourse clues, such as sub-titles or sub-section titles, paragraph as a unit of ideas, and other possible linguistic and discourse clues available in Indonesian language which might help chunking the text in to moves and identifying the move boundaries.

\subsection{Procedures of Communicative Unit Analysis}

The processes of identifying the communicative units in the discussion section of RAs went through the following steps: first, Reading the titles, the abstracts and the key terms to get a rough understanding of the research project reported in the RAs; second, reading the entire text to identify the main sections of the RAs; third, reading the discussion section of the RAs to identify the linguistic and discourse clues; fourth, identifying the communicative units in the discussion of the RAs; fifth, identifying the common discourse patterns of the discussion section of the RAs; and finally, developing an acceptable model of discourse pattern of moves (if possible) which characterizes the discussion section of RAs written in Indonesian by Indonesian writers. 
3.4 Sample Analysis of Communicative Units or Moves in a Sample of RAs

To show how identifying the communicative units in the discussion section of the RAs was done, an example of a discussion section in the data of this research is given below. The text sample is taken from the discussion section of psychology article titled "Hubungan Konsep Diri Dengan Motivasi Belajar Pada Siswa Kelas XI SMA PI Jakarta" (The Relationship Between Self Concept and Learning Motivation of Senior High School Students of XI Class of PI of Jakarta) written by Silvia Tjindaidi and Primus Domino (2009) published in 'Psibernetika' Journal, vol. 2 no. 1 pp: 23-31. For the purpose of this sample text analysis, only the discussion section is given below which is then followed by a free translation into English and the analysis of moves.

\section{$\underline{\text { Pembahasan }}$}

Hasil penelitian menunjukkan bahwa ada hubungan antara konsep diri siswa dengan motivasi belajar siswa dengan korelasi sebesar 0,729(S1). Hasil penelitian sesuai dengan pendapat dari James dalam Woolfolk (1993) yang mengatakan bahwa siswa yang memiliki konsep diri yang lebih positif berfikir bahwa semua aktifitas yang berkaitan dengan belajar adalah hal penting bagi dirinya sendiri(S2). Siswa harus memiliki keyakinan bahwa belajar itu penting bagi dirinya dan beranggapan bahwa kesuksesan diri disebabkan oleh tindakan diri sendiri, bukan karena keberuntungan atau oleh bantuan khusus(S3). Keyakinan ini memberi peningkatan yang besar dalam konsep diri sehingga siswa mampu berkembang dan berkompetisi di dalam lingkungan pendidikan (sekolah)(S4).

Hubungan yang siginifikan antara konsep diri dan motivasi belajar pada siswa kelas XI SMA PI juga disebabkan sikap yang sangat suportif dari guru kepada siswa dalam proses belajar mengajar(S5). Berdasarkan pengalaman dari peneliti ketika berhubungan dengan siswa SMA PI, tampak bahwa guru selalu berusaha memberikan semangat kepada sswa untuk belajar(S6). Dukungan yang kuat dari guru dalam bentuk dorongan untuk belajar, bimbingan belajar yang baik, metode pengajaran yang bermutu akan meningkatkan konsep diri siswa, nantinya berpengaruh pada peningkatan motivasi siswa dalam belajar(S7).

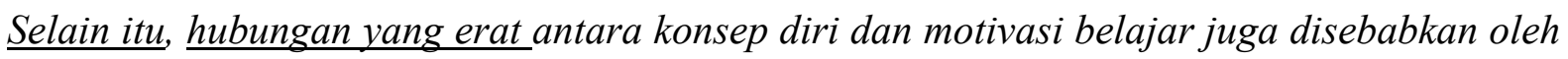
adanya konsep diri akademik pada siswa(S8). Konsep diri akademik adalah pandangan dan penilaian seorang siswa terhadap dirinya sendiri dalam kaitannya dalam berbagai perilaku belajar(S9). Contoh konsep diri akademik antara lain, motivasi dalam belajar dan berprestasi, relasi atau hubungan dengan guru dan teman, respon terhadap keberhasilan dan kegagalan(S10). Sedangkan konsep diri nonakademik adalah pandangan dan penilaian seorang siswa mengenai diri mereka sendiri dalam konteksnya dengan tingkah laku atau aktifitas di luar belajar(S11). Konsep diri akademik yang tinggi akan meningkatkan semangat siswa untuk belajar sehingga lebih berprestasi dibandingkan dengan siswa yang memiliki konsep diri nonakademik(S12).

\section{$\underline{\text { Discussion }}$}




\section{Mll Macrothink}

International Journal of Linguistics

ISSN 1948-5425

2013, Vol. 5, No. 4

The results show that there is a correlation between self-concept of the students and their motivation to study with the correlation of $0.729(\mathbf{S 1})$. This result is in line with what is claimed by James (quoted in Woolfolk, 1993) who states that the students with more positive self-concept think that all activites related to studying are important for them(S2). Students must be sure that studying is important for them and that their success is caused by their own effort; it is not just because of luck or special assistance from others(S3). This believe gives a bigger increase in their self-concept so that the students are able to develop and to compete in their environment of education (school)(S4).

Also, the signifcant correlation between self concept and learning motivation of the highschool students of class XI of PI is caused by the supporting attitude from their teachers in learning processes(S5). Based on my own experience when visiting and interacting with the students and teachers, it was obvious that the teachers always encouraged the students to study harder (S6). This teacher's supportive attitude toward the students, good learning guide, quality teaching methods will improve student's self concept which is then will improve student's learning motivation and learning results(S7).

Also, the significant correlation between self concept and student's learning motivation is caused by student's nonacademic self concept(S8). Student's academic self concept is their view on their own concerning various learning activities(S9). An example of academic self concepts among other things is learning motivation and motivation to succeed, relationship with teachers and friends, responses towards success and failures(S10). On the other hand, nonacademic self concept is the student's view on their own concerning nonacademic activities(S11). Compared to nonacademic self concept, student's high academic self concept will improve student's motivation to study better; then this will improve their learning results(S12).

In the above text, sentence 1 (S1) is classified as Move 2 (the statement of result) and sentence 2 (S2) is Move 4 (reference to previous research). Sentence 3 (S3) and sentence 4 (S4) are glossed as further explanation of the reference to previous research. Sentence 5 (S5), 6 (S6), 7 (S7) and sentence 8 (S8) are classified as Move 5 (explanation). Sentence 9 (S9), 10 (S10) and 11 (S11) can be classified as Move 1 (background information). The last sentence (S12) in this text is identified as Move 7 (deduction and hypothesis). Thus, the move structure in the above text looks like the following: Move $2-$ Move $4-$ Move $5-$ Move 1 and Move 7.

The linguistic and discourse clues which are used to help identify the moves in the above texts are as follows: 1) hasil penelitian ... (the results of the study...); 2) ... sesuai dengan pendapat .... ( in line with ...); 3) Selain itu, hubungan yang erat antara ... (Also, the signifcant correlation between...); 4) Berdasarkan pengalaman dari peneliti... (Based on my own experience...); 5) Selain itu,... (Also, ...);6) hubungan yang erat antara... (the signifcant correlation between...); 7) contoh ... (an example...); 8) adalah... (is ...); and sedangkan ... (on the other hand...). Other discourse clues are subheading (Diskusi or discussion), statistical numbers (the correlation of 0.729), source of reference (quoted in Woolfolk, 1993, and the most important one is my understanding on the information contained in the text. The more 


\section{MlMacrothink}

International Journal of Linguistics

ISSN 1948-5425

2013, Vol. 5, No. 4

discourse and/or linguistic clues are used in the RAs, the easier it is to analyse and to comprehend.

\section{Results and Discussion}

\subsection{Results}

The first analysis is on the macro structure of the results and discussion section of the RAs in the corpus of the study. It is found that in the majority of the RAs, the results and discussion section are collapsed into one section under the subheading Hasil Penelitian dan Pembahasan (Research Results and Discussion); there is no separate section under the subheading of diskusi or pembahasan (Discussion). The distribution of the discussion section in the RAs in which the two subsections are combined or separated is given in Table 2 below.

Table 2. The Macro Structure of Results and Discussion Section of RAs in Indonesian by Indonesian Writers

\begin{tabular}{|l|l|l|l|l|}
\hline \multirow{2}{*}{ No. } & \multirow{2}{*}{ Journal Disciplines } & Results and Discussion Section & \multirow{2}{*}{ Total } \\
\cline { 3 - 4 } & & Combined & Separated & \\
\hline 1. & Social sciences & 6 & 1 & 7 \\
\hline 2. & Psychology & 4 & 2 & 6 \\
\hline 3. & Education & 11 & 3 & 14 \\
\hline 4. & Religious studies & 2 & 2 & 4 \\
\hline 5. & Economy and management & 7 & 3 & 10 \\
\hline 6. & Language and literature & 5 & 1 & 6 \\
\hline \multicolumn{2}{|l|}{ Total } & 35 & 12 & 47 \\
\hline
\end{tabular}

As can be seen in the above table, in the majority of the RAs (36 or $74.5 \%$ ), the results and discussion subsections are collapsed into one section (Research Results and Discussion) and there is no separate part of the text only for discussion. In one RA of the social sciences journal, the results and discussion section is subheaded Kesimpulan dan Saran (Conclusion and Suggestion) and in one RA of the economy and management journals, the section is subheaded Pembahasan (Discussion) although it contains the display and description of research results and discussion. According to Andy Kirkpatrick (personal communication via email), it is common even in RAs published in international journals in the fields of social sciences and humanities to find the results and discussion are written in one section, not in two separate subsections as in RAs in the fields of natural and hard sciences.

The second analysis is the analysis of communicative units or moves in the discussion section of the RAs in the corpus of this study. If the subsection of results and discussions are collapsed in to one section as in the majority of the RAs in the corpus of this study, then both subsections were analysed by using the eight-move structure (EMS) model as discussed earlier in this article. For the RAs in which the results and discussion subsections are collapsed into one unit of discourse, both subsections were analysed and for the one in which the discussion subsection is separated, only the discussion subsection was analysed. The move analyses results are shown in Table 3 below. 
Table 3. Move Structure in the Indonesian RA Discussion Section

\begin{tabular}{|c|c|c|c|}
\hline RAs & Move Structure & $\begin{array}{l}\text { No of } \\
\text { Moves }\end{array}$ & $\begin{array}{l}\text { Average } \\
\text { Move/ } \\
\text { RA }\end{array}$ \\
\hline \multicolumn{4}{|c|}{ Social Science Journals (SS) } \\
\hline SS.1 & M1-M5-M2-M8 & 4 & \multirow{7}{*}{9.4} \\
\hline SS.2 & M1-M2-M1-M2-M7-M6-M7 & 7 & \\
\hline SS.3 & M2-M5-M4-M5-M2 & 5 & \\
\hline SS.4 & $\begin{array}{l}\text { M1-M2-M7-M2-M1-M2-M5-M1-M2-M5-M2-M1-M2-M5-M } \\
1\end{array}$ & 15 & \\
\hline SS.5 & M1-M2-M5-M2-M7-M4-M7 & 7 & \\
\hline SS.6 & $\begin{array}{l}\text { M1-M2-M1-M2-M1-M2-M1-M2-M1-M2-M1-M2-M1-M2-M } \\
\text { 8-M2-M8-M2-M7-M2-M8-M1-M2-M8 }\end{array}$ & 24 & \\
\hline SS.7 & M2-M5-M2-M8 & 4 & \\
\hline \multicolumn{4}{|c|}{ Psychology Journals (PJ) } \\
\hline PJ.1 & M2-M5-M2-M8 & 4 & \multirow{6}{*}{10.2} \\
\hline PJ.2 & $\begin{array}{l}\text { M2-M5-M2-M5-M2-M4-M8-M2-M5-M2-M4-M5-M1-M2-M } \\
\text { 5-M8 }\end{array}$ & 16 & \\
\hline PJ.3 & M1-M2-M5-M1-M2-M5-M2-M1-M2 & 9 & \\
\hline PJ.4 & M2-M4-M5-M6-M5 & 5 & \\
\hline PJ.5 & M1-M2-M5-M4-M2-M5-M8-M4-M2-M5-M1-M4-M5-M7 & 14 & \\
\hline PJ.6 & M1-M2-M5-M2-M5-M2-M5-M2-M5-M4-M5-M4-M5 & 13 & \\
\hline \multicolumn{4}{|c|}{ Education Journals (EJ) } \\
\hline EJ.1 & M1-M2-M5-M1-M2-M8 & 6 & \multirow{14}{*}{6.4} \\
\hline EJ.2 & M1-M2 & 2 & \\
\hline EJ.3 & M1-M2-M7-M1-M2-M5-M7-M2-M4-M2-M5-M2 & 12 & \\
\hline EJ.4 & M1-M2-M7 & 3 & \\
\hline EJ.5 & M1-M2-M8-M7-M2-M8 & 6 & \\
\hline EJ.6 & M2-M4-M8-M4-M8-M2-M7 & 7 & \\
\hline EJ.7 & $\begin{array}{l}\text { M1-M2-M5-M1-M2-M1-M2-M5-M2-M1-M2-M5-M2-M5-M } \\
2\end{array}$ & 15 & \\
\hline EJ.8 & M1-M2-M5 & 3 & \\
\hline EJ.9 & M2-M7 & 2 & \\
\hline EJ.10 & M1-M2 & 2 & \\
\hline EJ.11 & M2-M7 & 2 & \\
\hline EJ.12 & M1-M2-M5-M7-M8-M2-M7 & 7 & \\
\hline EJ.13 & M1-M2-M1-M2-M5-M7 & 6 & \\
\hline EJ.14 & M1-M2-M4-M5-M2-M1-M2-M1-M2-M6-M8-M2-M6-M2-M & 16 & \\
\hline
\end{tabular}




\begin{tabular}{|c|c|c|c|}
\hline & 7 & & \\
\hline \multicolumn{4}{|c|}{ Journal of Religious Studies (RS) } \\
\hline RS.1 & $\begin{array}{l}\text { M1-M4-M5-M1-M2-M5-M8-M4-M2-M5-M4-M1-M2-M3-M } \\
\text { 5-M3 }\end{array}$ & 16 & \multirow{4}{*}{9} \\
\hline RS.2 & M1-M2 & 2 & \\
\hline RS.3 & M1-M2-M1-M2-M7-M2-M5-M6-M5-M2-M7 & 11 & \\
\hline RS.4 & M2-M5-M4-M2-M5-M1 & 7 & \\
\hline \multicolumn{4}{|c|}{ Economy and Management Journals (EM) } \\
\hline EM.1 & $\begin{array}{l}\text { M2-M5-M4-M5-M4-M2-M5-M4-M2-M7-M5-M4-M8-M2-M } \\
\text { 5-M4-M2-M4-M5-M8-M4-M7-M8 }\end{array}$ & 23 & \multirow{10}{*}{11.7} \\
\hline EM.2 & $\begin{array}{l}\text { M2-M4-M5-M2-M1-M2-M1-M2-M5-M4-M2-M5-M2-M1-M } \\
\text { 2-M1-M2-M1-M2 }\end{array}$ & 19 & \\
\hline EM.3 & M2-M7 & 2 & \\
\hline EM.4 & M1-M2-M5-M2-M7-M2 & 7 & \\
\hline EM.5 & $\begin{array}{l}\text { M1-M2-M7-M2-M1-M2-M7-M2-M5-M2-M7-M1-M2-M5-M } \\
\text { 2-M8 }\end{array}$ & 16 & \\
\hline EM.6 & M2-M5-M2-M5-M2-M5-M2-M5-M2-M5-M2-M5 & 12 & \\
\hline EM.7 & M2-M5 & 2 & \\
\hline EM.8 & M1-M2-M1-M2-M8-M1-M2-M8 & 8 & \\
\hline EM.9 & M2-M4-M5-M2-M4-M2-M8-M2-M4-M8-M7-M2-M7 & 13 & \\
\hline $\begin{array}{l}\text { EM.1 } \\
0\end{array}$ & $\begin{array}{l}\text { M2-M5-M4-M2-M5-M4-M2-M5-M4-M2-M5-M4-M2-M5-M } \\
4\end{array}$ & 15 & \\
\hline \multicolumn{4}{|c|}{ Language and Literature Journals (LL) } \\
\hline LL.1 & M2-M4-M2 & 3 & \multirow{6}{*}{10} \\
\hline LL.2 & M1-M2 & 2 & \\
\hline LL.3 & M1-M2-M4-M5-M4-M2-M4-M2 & 8 & \\
\hline LL.4 & M1-M2-M4-M2-M1-M2-M1-M2-M7-M2 & 10 & \\
\hline LL.5 & $\begin{array}{l}\text { M7-M1-M2-M7-M2-M7-M1-M2-M1-M2-M1-M2-M1-M2-M } \\
\text { 7-M2-M7 }\end{array}$ & 17 & \\
\hline LL.6 & $\begin{array}{l}\text { M1-M2-M1-M2-M1-M2-M1-M2-M5-M2-M5-M2-M5-M2-M } \\
\text { 5-M2-M5-M2-M1-M2 }\end{array}$ & 20 & \\
\hline
\end{tabular}

The move structure, as seen in Table 3 above, is shown through the list of moves found the discussion subsection or result and discussion section in the RAs in the corpus of this study. Thus, the structure of M1-M2-M5-M8 indicates that the discussion section started with background information, then folowed by statement of results, then by explanation and ended with a recommendation. It is obvious that the number of moves in each RA is very various ranging from 2 to 24 moves; this is partly because in several RAs the results and discussion subsections are combined and the conclusion and reccommendation section is added as one section. Thus, the macro structure for the majority of the RAs in the corpus of this study is not introduction, method, results and discussion (IMRD), but introduction, method, results and discussion and conclusion and recommentaion (IMRDC\&R).

The variation among the discussion section of RAs in different disciplines in terms of the 
number of moves is not significant; the average number of moves ranges from 6.4 in Journals of Education to 11.7 in Journals of Economy and Management. The variation is even greater in the internal group of journal itself; for eample in RAs of Language and Literature (LL), there is an RA with only 2 moves in its discussion section but there is also an RA with 20 moves in its discussion section. It seems that the number of moves in the results and discussion section of the RA depends on the complexity of the research project reported in the RAs or the number of research questions dealt with. Thus, it seems that there is not yet any standard structure of move in the discussion section of the RAs in Indonesian written by Indonesian writers.

Another analysis result necessary to address here is that in several RAs in the corpus of this study very few linguistic and discourse markers or even misleading markers are used. The examples of the absence or wrongly use of linguistic and discourse markers are given below:

a) There is no subheading 'Result and Discussion' at all in the RAs; the information about results and discussion is given under a subheading of Kesimpulan dan Saran (Conclusion and Recommendation) (LL.6) and (SS.1);

b) It is not clearly stated whether the results being discussed is the one from previous relevant studies or the one from the present study (LL.2), (SS.7), (EM.8), and (EJ.3);

c) The results and discussion section is subheaded only with Hasil (Results) (SS.4) or only with Pembahasan (Discussion) (RS.4) and (EM.10); and

e) Reference to previous research is not written in a standard way; there is no information about the source of the research findings (SS.5).

The wrong and/or lack of linguistic and discourse markers in RAs may result in misunderstanding, misinterpretation or difficulties in comprehending of the RAs by the readers especially for those who are new to the particular discourse community of RAs in these disciplines, such as university students, novice writers or researchers, new practitioners in the fields or the second or foreign language speakers in which the RAs are written.

The most important information from the data of this study is probably the distribution of eight different moves in six different journals in the corpus of this study. The distribution is shown in Table 4 below:

Table 4. Distribution of Eight Different Moves in Six Different Journals in the Corpus of this Study

\begin{tabular}{|l|l|l|l|l|l|l|l|}
\hline Moves Journals & $\begin{array}{l}\text { SS } \\
\mathrm{n}=7\end{array}$ & $\begin{array}{l}\text { PJ } \\
\mathrm{n}=6\end{array}$ & $\begin{array}{l}\text { EJ } \\
\mathrm{n}=14\end{array}$ & $\begin{array}{l}\mathrm{RS} \\
\mathrm{n}=4\end{array}$ & $\begin{array}{l}\mathrm{EM} \\
\mathrm{n}=10\end{array}$ & $\begin{array}{l}\text { LL } \\
\mathrm{n}=6\end{array}$ & $\begin{array}{l}\text { Total } \\
\mathrm{N}=47\end{array}$ \\
\hline $\begin{array}{l}\text { Move 1 (Background } \\
\text { information) }\end{array}$ & 5 & 4 & 11 & 4 & 4 & 4 & 32 \\
\hline $\begin{array}{l}\text { Move 2 (Statement of } \\
\text { results) }\end{array}$ & 7 & 6 & 14 & 4 & 10 & 6 & 47 \\
\hline $\begin{array}{l}\text { Move 3 ((Un)expected } \\
\text { outcome) }\end{array}$ & - & - & - & 1 & - & - & 1 \\
\hline
\end{tabular}




\begin{tabular}{|l|l|l|l|l|l|l|l|}
\hline $\begin{array}{l}\text { Move 4 (Reference to } \\
\text { previous studies) }\end{array}$ & 2 & 4 & 3 & 2 & 4 & 3 & 18 \\
\hline Move 5 (Explanation) & 5 & 6 & 7 & 3 & 8 & 2 & 31 \\
\hline Move 6 (Exemplification) & 1 & - & 1 & 1 & - & - & 3 \\
\hline $\begin{array}{l}\text { Move 7 (Deduction \& } \\
\text { hipothesis) }\end{array}$ & 3 & 1 & 9 & 1 & 5 & 1 & 20 \\
\hline $\begin{array}{l}\text { Move } \\
\text { Re-commendation) }\end{array}$ & 3 & 3 & 3 & 1 & 4 & - & 14 \\
\hline
\end{tabular}

The most frequent move found in the discussion section of RAs in Indonesian written by Indonesian writers in the fields of social sciences and humanities, as shown in Table 4, is Move 2 (statement of results) and the second most frequent move is Move 1 (background information). The intresting finding here is the occurence of Move 5 (explanation) which outnumbers the occurence of Move 4 (reference to previous studies). As can be seen in Table 4 above only 18 RAs $(38.3 \%)$ has a move 4 while 31 RAs $(66 \%)$ has a move 5 . This seems to be the most noticeable difference between discussion section of RAs in Indonesian written by Indonesian writers in the fields of social sciences and humanities and the ones in English as far as the move structure is concerned. The similarity between the RAs in Indonesian and the one in English is that several moves particularly Move 1 (background information) and Move 2 (statement of results) are cyclical; this means that the occurence of a Move 1 is very likely to be followed by a Move 2 as often found in the academic discourse.

\subsection{Discussion}

The first research question in this study is what communicative purpose segments or moves are dominantly found in the discussion section of RAs in the disciplines of social science and humanities written in Indonesian by Indonesian writers are. As indicated in the results section of this study, the most dominant moves found in the discussion section of the RAs in the corpus of this study are Move 1 (background information), Move 2 (statement of results), and Move 5 (explanation). This finding is different from the one suggested by Swales (1990) and Dudley-Evans (1994) where they claim that the most common Moves in the discussion section of RAs in English are a cycle of Move 1, Move 2, and Move 4 (reference to previous studies). The use of Move 5 in the Indonesian RAs seems to replace Move 4; that is the idea that every finding must be elaborated and explained further so that readers understand what it means. This implies that, unlike the authors of English RAs as claimed by Swales (1990), discussing the research findings from the view of available knowledge or previous relevant research findings is not important for Indonesian authors while for English authors this is very important in order to show the contribution of the present research to the available knowledge on the discipline.

The second research question is whether or not there is any difference between the six groups of the RAs in the disciplines of education, economy and management, language and literature, social sciences, psychology and religious studies in the corpus of this study in terms of the use of communicative units or moves. As stated in the results section of this study that there is no significant difference between the six groups of RAs in terms of the existence of the 
moves in the discussion section; however, a noticeable difference occurs between the RAs within the same discipline. This is probably because of the different complexity of the research projects reported in these RAs. Usually the research projects funded by a government institution in Indonesia, such as by a university or the directorate general of higher education of Indonesia or the one conducted to write a thesis or dissertation in order to complete a university degree is more serious and complex than the one which is self funded. More serious or complex research projects usually address more research questions and therefore give more results or findings than the simpler ones do.

The last question addressed in this study is whether or not there is a main difference between the move structure found in the discussion section of Indonesian RAs and the one in English. As identified above the most noticeable difference is the absence of Move 4 (reference to previous research) in the majority of the discussion section of the Indonesian RAs. One possible reason for this finding is that it is common for Indonesian writers in social science and humanities to justify their research project only on the fact that there is a problem on an important topic without bothering to find the research space or 'niche' to use Swales' term from the findings of previous relevant studies (Safnil, 2000). This seems to affect the ways the writers discuss their research findings in which they may find it unnecessary to link it to the findings of previous relevant studies as far as all research objectives have been met or all research questions have been answered. Similar findings were obtained by Basthomi (2009) when he analyzed the introduction section of doctoral dissertation of State University of Malang, Indonesia. He found that although the writers review relevant literature in the 'background of the study' section of the dissertation, the majority of the reference to relevant literature is about discussion on theoretical concepts which might have been obtained from reference books rather than from RAs.

A similar finding was found by Holmes (1997) that, unlike the RAs in political sciences and sociology, the discussion section of RAs in the discipline of history in the corpus of his study rarely has reference to the previous research findings or Move 4 (in Swales' model). According to Holmes, one of the reasons is that the research practices in this discipline have not yet developed together among the researchers and there seems to be no agreement among the researchers or writers in this discipline on standard format of knowledge production and expression.

\section{Conclusions and Recommendation}

\subsection{Conclusions}

From the results and discussion of this study as discussed above, several conclusions can be drawn as follows:

1). It is found that in the majority of the RAs in the corpus of this study, the results and discussion sections are collapsed into one section under the subheading of Hasil Penelitian dan Pembahasan (Research Results and Discussion); there is no separate section under the subheading of diskusi or pembahasan (Discussion).

2). The most dominant moves found in the discussion section of the RAs are Move 1, Move2, 
and Move 5.

3). There is no significant difference between the six groups of RAs in terms of the occurrence of moves in the discussion section; however, the noticeable difference occurs between the RAs within the same discipline.

4). The most noticeable difference between the discussion section of RAs in Indonesian and the one in English is the absence of Move 4 (reference to previous research) in the majority of the discussion section of the Indonesian RAs while it is a compulsory move in the English RA discussion section.

\subsection{Recommendation}

The obvious recommendation from the findings of this study is for the Indonesian writers who are going to publish their RAs in an international journal in English in which they have to adjust their RA rhetorical styles to suit the one acceptable in English in all sections including the discussion section. It is not sufficient to improve only the quality of the research project in terms of the importance of the research topic and the sounding of the research method used but they have to base their study on the knowledge gap not just on a practical problem.

For English lecturers at university in Indonesia, it is suggested that they should make the students aware of the rhetorical differences and similarities between Indonesian and English academic texts. It is very important for Indonesian students and/or authors to use English rhetorical styles when writing academic texts in English. The important aspect of academic writing is not only on the content quality of the text but also the writing or rhetorical style; that is how it is appropriately and correctly written in English so that it is acceptable for English speakers to read it.

This analysis of communicative units in the discussion section of the RAs was done by one person; therefore, individual bias or subjectivity might have been involved in the analysis results. In order to reduce the subjectivity, it is advisable that the future studies should go through triangulation processes by involving other academics who are familiar with this work to analyze all or samples of the RAs. Also, in the corpus of this study there is only one article chosen from one journal which might not represent all articles published in the journals. Thus, it is advisable that for future similar studies more articles from the same journal are taken in order to ensure the representativeness of the data of the study so that the results or findings are more valid and reliable.

\section{References}

Ariwibowo, A. A. (2008). Publikasi Internasional Penelitian Indonesia Rendah. Retrieved from www.antaranews.com

Basthomi, Yazid (2009). Examining Research Spaces in Doctoral Prospectuses. TEFLIN Journal, 20(2), 140-158.

Basturkemn, Helen. (2012). A Genre-based Investigation of Discussion Sections of Research 
Articles in Dentistry and Disciplinary Variation. Journal of English for Academic Purposes, 11(2), 134-144. http://dx.doi.org/10.1016/j.jeap.2011.10.004

Belcher, Wendy Laura. (2009). Writing Your Journal Article in Twelve Weeks: A Guide to Academic Publishing Success, California: SAGE Publications, Inc.

Branson, Richard D. (2004). Anatomy of a Research Paper. Respiratory Care, 49(10), 1222-1228.

Dudley-Evans, Tony 'Genre Analysis: an Approach to Text Analysis for ESP'. In Malcolm Coulthard (1994) (Ed.) Advances in Written Text Analysis, London: Routledge.

Hagin, Stephen. (2009). How to Write the Results and Discussion Sections, English 1102/66 of Kennesaw State University, Spring 2009.

Hess, Dean R. (2004). How to Write an Effective Discussion. Respiratory Care, 49(10), 1238-1241.

Holmes, Richard. (1997). Genre Analysis, and the Social Sciences: An Investigation of the Structure of RA Discussion Sections in Three Disciplines. English for Specific Purposes, 16(4), 321-327. http://dx.doi.org/10.1016/S0889-4906(96)00038-5

Parkinson, Jean. (2011). The Discussion Section as Argument: The Language Used to Prove Knowledge Claims. English for Specific Purposes, 30(3), 164-175. http://dx.doi.org/10.1016/j.esp.2011.03.001

Safnil. (2000). Genre Structure Analyses of the Indonesian Research Articles, unpublished Ph.D. Dissertation, the Australian National University, Canberra Australia.

Salimi, Samira, \& Morteza Yazdami. (2011). 'Move Analysis of the Discussion Section of Sociolinguistics and Testing Articles: Are Standard Met?', a paper presented at International Conference on Language, Literature and Linguistics, vol. 26 IACSIT Press, Singapore.

Swales, John M. (1990). Genre Analysis: English in Academic and Research Settings, Cambridge: Cambridge University Press.

Thyer, Bruce A. (2008). Preparing Reseach Articles, Oxford: Oxford Uniersity Press. http://dx.doi.org/10.1093/acprof:oso/9780195323375.001.0001

Wahid, Fathul. (2011). Publikasi Internasonal Akademisi Indonesia, Kolom Analisis SKH Kedaulatan Rakyat, 9 September.

\section{Glossary}

RA: Research Article

LL : Language and Literature

IMRDC\&R : Introduction, Method, Results, Discussion, Conclusion and Recommendation

M : Move 
EMS : Eight Move Structure

S : Sentence

Appendix

Appendix1. The Research Articles Included in the Corpus of the Study

\begin{tabular}{|c|c|}
\hline SS.1 & $\begin{array}{l}\text { Agus and Aminuddin (2011) 'Pengaruh Gaya Kepemimpinan Terhadap Kinerja } \\
\text { Apartur Dinas Pertanian dan Kehuatanan Kota Kendari,' in Jurnal Publika, vol. 2, } \\
\text { no. } 2 \text { pp:124-129 }\end{array}$ \\
\hline SS.2 & $\begin{array}{l}\text { Hardianto, Willy Tri (2011) 'Peranan Motivasi Serta Disiplin Kerja Dala } \\
\text { Meningkatkan Pelayanan Publik di Era Otonomi Daerah', in Reformasi, vol. 1, } \\
\text { no.1 pp:7-11 }\end{array}$ \\
\hline SS.3 & $\begin{array}{l}\text { Hanifah, Abu and Hemat Sitepu (2010) 'Ketahan Sosial Masyarakat dalam } \\
\text { Perspektif Agama dan Etnis' in Jurnal Penelitian dan Pengembangan } \\
\text { Kesejahteraan Sosial, vol. 15, no.1 pp:13-22 }\end{array}$ \\
\hline SS.4 & $\begin{array}{l}\text { Putra, I Nyoman Adijaya (2008) 'Pilihan Kode Masyarakat Tutur Muslim } \\
\text { Pengayaman' in Penelitian dan Pengembangan Sain dan Humaniora, vol.2, no.1 } \\
\text { pp:1-13 }\end{array}$ \\
\hline SS.5 & $\begin{array}{l}\text { Sitepu, Anwar (2009) 'Model, Peluang dan Tantangan Pembentukan Pusat layanan } \\
\text { Kesejahteraan Sosial di Kecamatan', in Jurnal Penelitian dan Pengembangan } \\
\text { Kesejahteraan Sosial, vol. 14, no.02 pp:110-121 }\end{array}$ \\
\hline SS.6 & $\begin{array}{l}\text { Noorizatil, Linda and Alim Bakri (2011) 'Kajian Indeks Pembanguan manusia } \\
\text { Bidang Ekonomi di Kalimantan Selatan, in Kebijakan Pembanguan, vol.6, no.1 } \\
\text { pp:1-14 }\end{array}$ \\
\hline SS.7 & $\begin{array}{l}\text { Suwacana, Wayan Gede (2011) 'Kehidupan DemokRAsi pada Masyarakat Bali } \\
\text { Aga di Desa Adat Tengganan Penggringan karang Asem Bali’ in Penelitian } \\
\text { Sejarah dan Nilai Tradisional, vol.18, no.1pp:17-30 }\end{array}$ \\
\hline PJ.1 & $\begin{array}{l}\text { Pridayanti (2011) 'Pengaruh Komitmen Karir dan Kesuksesan Karir Subjektif } \\
\text { terhadap Kesiapan Menghadapi Perubahan', in Psymphatic, vol.4, no.1 } \\
\text { pp:232-239 }\end{array}$ \\
\hline PJ.2 & $\begin{array}{l}\text { S. K. Purwanto (2011) 'Peranan Sumber Daya Manusia dalam Membangun daya } \\
\text { Saing Perguruan Tinggi' in Psikobuana, vol.3, no.2 pp:73-83 }\end{array}$ \\
\hline PJ.3 & $\begin{array}{l}\text { Suparno (2006) 'The Influence of Management Information Stimulation Toward } \\
\text { Medic Personnel Performances Motive, in Psikovidya, vol.10, no.2, pp:63-68 }\end{array}$ \\
\hline PJ.4 & $\begin{array}{l}\text { Tjindaily, Silvia and Primus Domino (2009) 'Hubungan Konsep Diri dengan } \\
\text { Motivasi Belajar pada Siswa Kelas XI SMA PI Jakarta' in Psibernetika, vol.2, } \\
\text { no.1 pp:23-31 }\end{array}$ \\
\hline PJ.5 & $\begin{array}{l}\text { Prihatsanti, Unika (2010) 'Hubungan Kepuasan Kerja dan Need for Achievement } \\
\text { dengan Kecendrungan Resitance to Change pada Dosen UNDIP Semarang' in } \\
\text { Jurnal Psikology UNDIP, vol.8, no.2 pp:78-86 }\end{array}$ \\
\hline PJ.6 & $\begin{array}{l}\text { Raharjo, Wahyu (2010) 'Harga Diri dan pengalaman Melakukan Aktifitas Seks } \\
\text { Online pada Mahasiswa Pria' in Psikobahra, vol.1, no.1 pp:1-10 }\end{array}$ \\
\hline EJ.1 & Abdulkarim, Aim (2007) 'Analisis Isi Buku Teks dan Implikasinya dalam \\
\hline
\end{tabular}




\begin{tabular}{|c|c|}
\hline & $\begin{array}{l}\text { Memberdayakan Keterampilan Berpikir Siswa SMA' in Forum Kependidikan, } \\
\text { vol.26, no.2 pp:118-132 }\end{array}$ \\
\hline EJ.2 & $\begin{array}{l}\text { Elizabeth, Ranu Melia (2008) 'Peningkatan Prestasi Belajar Mahasiswa Dalam } \\
\text { Mata Kuliah Teknologi Perkantoran dengan Pembelajaran langsung' in } \\
\text { Pendidikan Ekonomi, vol.1., no.1 pp:1-12 }\end{array}$ \\
\hline EJ.3 & $\begin{array}{l}\text { Patmadewi, Ni Nyoman (2010) 'Model Pengentasan Kemiskinan dalam Upaya } \\
\text { Peningkatan Pemerataan Pendidikan' in Penelitian Inovasi dan Rekayasa } \\
\text { Pendidikan, vol.1, no.1 pp:1-30 }\end{array}$ \\
\hline EJ.4 & $\begin{array}{l}\text { Kartono; Marwiyanto; Noer Hidayah (2010) 'Peningakatan Kreatifitas dan } \\
\text { Motivasi Blajar IPA Melalui Pembelajaran Kontekstual Siswa Kelas V SD } 3 \\
\text { Karang Asem Laweyan Surakarta' in Didaktika Dwija Indria, vol.1, no.1, pp:1-21 }\end{array}$ \\
\hline EJ.5 & $\begin{array}{l}\text { Nurhidayati and Abraham Nur Cahyo (2012) 'Kesadaran Sejarah dan Partisipasi } \\
\text { Masyarakat dalam Pelestarian Monumen Jenderal Sudirman: Studi Kasus di Desa } \\
\text { Pakis Baru Kec. Nawangan Kab. Pacitan’ in Agastya, vol.2, no.1, pp:25-42 }\end{array}$ \\
\hline EJ.6 & $\begin{array}{l}\text { Sastrawati, Eka; Rusdi Muhammad and Syamsurizal (2011) 'Problem-Based } \\
\text { Learning, Strategi Meta Kognisi, dan Keterampilan Berpikir Tingkat Tinggi } \\
\text { Siswa' in Tekno-Pedagogi, vol.1, no.2 pp:1-14 }\end{array}$ \\
\hline EJ.7 & $\begin{array}{l}\text { Nurudin (2010) 'Proses kebijakan Pendidikan Gratis Pasca Pemilihan Kepala } \\
\text { Daerah Langsung di Kabupaten Banyuwangi' in Edukasi, vol.8, no.2 } \\
\text { pp:4057-4073 }\end{array}$ \\
\hline EJ.8 & $\begin{array}{l}\text { Yudianto, Erfan (2012) 'Profil Pengajuan Soal Mahasiswa Calon Guru } \\
\text { Berkemampuan Rendah' in Admathedu, vol.2, no.1 pp:1-10 }\end{array}$ \\
\hline EJ.9 & $\begin{array}{l}\text { Hani, Umu dkk. (2012) 'Hubungan Antara Budaya Organisasi dan Etos Kerja } \\
\text { Guru dengan Mutu Layanan Sekolah Pada MadRAsah Tsanawiyah Negeri di Kec. } \\
\text { Cakung Jakarta Timur' in Akademika, vol.1, no.1 pp:37-54 }\end{array}$ \\
\hline EJ.10 & $\begin{array}{l}\text { Wibowo, Elias Noer (2012) 'Peningkatan Kreatifitas dan Hasil Belajar } \\
\text { Matematika Materi Himpunan Melalui Pendekatan Pembelajaran Problem Posing } \\
\text { Bagi Siswa Kelas VII A SMP Negeri } 1 \text { Purwokerto' in Bhakti Utama, vol.3, no.4 } \\
\text { pp:12-21 }\end{array}$ \\
\hline EJ.11 & $\begin{array}{l}\text { Ranto, Basuki (2011) 'Pengaruh Return on Investment of Human Capital } \\
\text { (ROIHC) Efektifitas Terhadap Kinerja Organisasi: Studi Kasus Pada PT TGU } \\
\text { Jakarta 2011' in Manajemen Pendidikan,vol.1, no.2 pp:101-109 }\end{array}$ \\
\hline EJ.12 & $\begin{array}{l}\text { Setyaningsih (2010) 'Peningkatan keterampilan Menyimak (Listening) dan } \\
\text { Berbicara (Speaking) pada Pelajaran bahasa Inggris Melalui Metode Pair-check' in } \\
\text { Didaktikum, vol. 1, no.3 pp:288-297 }\end{array}$ \\
\hline EJ.13 & $\begin{array}{l}\text { Zamzani Dkk. (2006) 'Peningkatan Perkuliahan Bahasa Indonesia untuk Membina } \\
\text { Kterampilan Mahasiswa Dalam Menulis karya Ilmiah' in Cakrawala Pendidikan, } \\
\text { vol.25, no.2 pp:309-325 }\end{array}$ \\
\hline EJ.14 & $\begin{array}{l}\text { Setyaningsih, Yuliana (2008) 'Peningkatan Kemampuan Menulis Argumentatif } \\
\text { dan Keterampilan Berpikir Kritis Berbahasa Indonesia Mahasiswa melalui Model } \\
\text { Pembelajaran logika Toulmin' in Educationist, vol. 2, no.2 pp:98-111. }\end{array}$ \\
\hline RS.1 & $\begin{array}{l}\text { Rahmawati, Anita (2008) 'Analisis Pemicu Perbedaan Motivasi Nasabah } \\
\text { Berafiliasi di Bank Syariah di Semarang' in Islam Empirik, vol.2, no.1 pp:1-29 }\end{array}$ \\
\hline
\end{tabular}




\begin{tabular}{|c|c|}
\hline RS.2 & $\begin{array}{l}\text { Sulaiman, Ahmad (2012) 'Peranan Bimbingan Belajar Teknik Mata Pelajaran } \\
\text { Bahasa Inggris pada Siswa Sekolah Dasar' in Ukuwah, vol.7, no.2 pp:111-113 }\end{array}$ \\
\hline RS.3 & $\begin{array}{l}\text { Suwarnaya, I Putu (2008) 'Upaya Peningkatan Mutu Pembelajaran Agama Hindu } \\
\text { Melalui Penerapan Model Pembelajaran Active Learning berbasis CTL Pada } \\
\text { Siswa Kelas VII A } 1 \text { Semester Ganjil SMP Negeri } 1 \text { Singaraija' in Widya Sastra, } \\
\text { vol.4, no.6 pp:1-28 }\end{array}$ \\
\hline RS.4 & $\begin{array}{l}\text { Jasuri (2010) 'Kepemimpinan Kiyai Politikus Dalam Meningkatkan ESQ Santri } \\
\text { Pondok Pesantren Darussalam Tambak Selo Wirosari Grobongan' in I nferensi, } \\
\text { vol.4, no. } 2 \text { pp:1-19 }\end{array}$ \\
\hline EM.1 & $\begin{array}{l}\text { Wahyuningsih, Tri (2012) 'Pengaruh Investasi Pemerentah Terhadap Pertumbuhan } \\
\text { Ekonomi dan Kesejarteraan Masyarakat setelah Pmekaran Daerah Kabupaten dan } \\
\text { Kota di Propinsi Maluku' in Retemena, vol.1, no.1 pp:9-20 }\end{array}$ \\
\hline EM.2 & $\begin{array}{l}\text { Hartati, Anny (2009) 'Peningkatan Pendapatan Petani di Kabupaten Banyumas } \\
\text { dengan Cara Memberdayakan Petani Padi Organik melalui Kemitraan' in Soca, } \\
\text { vol.9, no.1 pp:1-5 }\end{array}$ \\
\hline EM.3 & $\begin{array}{l}\text { Suratman, Sasa Syaifulrohman (2012) 'Hubungan Finansial Disstres dan } \\
\text { Konservatisme Akuntansi' in Gema, vol.4, no.2 pp:119-131 }\end{array}$ \\
\hline EM.4 & $\begin{array}{l}\text { Widodo, Haryanto (2009) 'Analisis Kelayakan Investasi Perkebunan Kelapa Sawit } \\
\text { PT XYZ' in Organisasi dan Manjemen, vol.2, no.4 pp:1-26 }\end{array}$ \\
\hline EM.5 & $\begin{array}{l}\text { Kumanau, Anderson G. and Debi C. Rotinsulu (2009) 'Analisis Kemampuan } \\
\text { Keuangan Daerah Dalam Pembiayaan Pembanguan di Kabupaten Kepulauan } \\
\text { Sangihe' in Pmbanguan Ekonomi dan Kuangan Daerah,vol. 2, no.3 pp:1-26 }\end{array}$ \\
\hline EM.6 & $\begin{array}{l}\text { Foenay, Kristien Corina (2010) 'Analisa Pengaruh Faktor Internal Terhadap } \\
\text { Dividen Tunai pada Emiten Nonkeuangan di Bursa Efek Indonesia' in Bisnis dan } \\
\text { Manajemen, vol.2, no.1 pp:403-414 }\end{array}$ \\
\hline EM.7 & $\begin{array}{l}\text { Hidayat, Cecep and Pritha Putri Warahapsara (2010) 'Pengaruh Kualitas } \\
\text { Pelayanan dan Produk Terhadap Citra Perusahaan dan Loyalitas Nasabah' in } \\
\text { Jurnal Manajemen, vol.1, no.2 pp:95-102 }\end{array}$ \\
\hline EM.8 & $\begin{array}{l}\text { Nainggolan, Elfirisma T. Dkk (2011) 'Kelayakan dan Strategi Pengembangan } \\
\text { Usaha Silo Jagung di Gapoktan Ridomanah Kcamatan Nagreg Kabupaten } \\
\text { Bandung' in Manajemen IKM, vol.6, no.1 pp:1-8 }\end{array}$ \\
\hline EM.9 & $\begin{array}{l}\text { Akhyar, Khairil Dkk. (2010) ‘Pengaruh Partisipasi Anggaran, Gaya } \\
\text { Kepemimpinan dan Komitmen Organisasi Terhadap Kinerja Manjerial; Studi } \\
\text { Kasus Pada Universitas Malikus Saleh Loksmawe’ in Mepa, vol.5, no.1 pp:1-14 }\end{array}$ \\
\hline EM.10 & $\begin{array}{l}\text { Setyawan, Danil Budi (2006) 'Analisis Perusahaan Jasa Transportasi dan } \\
\text { Permintaan yang Bergerak Dengan Parameter Ebitda dan Ebit' in Tadulako, vol.7, } \\
\text { no.1 pp:2608-2622 }\end{array}$ \\
\hline LL.1 & $\begin{array}{l}\text { Indica, Canna (2011) 'Semangat Kebangsaan dalam Roman Drama di Boven } \\
\text { Digul Karya Kwee Tekhaai' in Bahasa dan Sastra, vol.11, no.2 pp:134-143 }\end{array}$ \\
\hline LL. 2 & $\begin{array}{l}\text { Mulyani, Mimi (2012) 'Sintakmatik Pembelajaran Menulis Catatan Harian } \\
\text { Berbasis Kearifan Budaya Lokal: Suatu Alternatif Model Pembelajaran } \\
\text { Keterampilan Menulis yang Berorientasi Pada Pendidikan Karakter' in } \\
\text { Metalingua, vol.10, no.1 pp:27-39 }\end{array}$ \\
\hline
\end{tabular}




\begin{tabular}{|l|l|}
\hline LL.3 & $\begin{array}{l}\text { Fauziah, Jiah (2011) 'Fitur-Fitur Fonologis Penggunaan Elemen-Elemen Bahasa } \\
\text { Arab Dalam Komunikasi Masyarakat Keturunan Arab Surakarta' in Adabiyyat, } \\
\text { vol.10, no.2 pp:207-232 }\end{array}$ \\
\hline LL.4 & $\begin{array}{l}\text { Faturrohman (2004) 'Kode Bahasa dalam Interaksi Sosial Santri: Kajian } \\
\text { Sosiolinguistik di Pesantern Banyumas' in Litera, vol.3, no.1 pp:12-26 }\end{array}$ \\
\hline LL.5 & $\begin{array}{l}\text { Arono (2005) 'Praanggapan dan Implikatur Wacana Dialog Dalam Pembelajaran } \\
\text { Bahasa Indonesia' in Wacana, vol.13, no.2 pp:169-187 }\end{array}$ \\
\hline LL.6 & $\begin{array}{l}\text { Amir, Johar (2011) 'Sapaan Dalam Bahasa Bugis Dialek Sidrap' in Linguistik } \\
\text { Indonesia, vol.29, no.1 pp:70-83 }\end{array}$ \\
\hline
\end{tabular}

\section{Copyright Disclaimer}

Copyright for articles published in this journal is retained by the author, with first publication rights granted to the journal.

This article is an open-access article distributed under the terms and conditions of the Creative Commons Attribution license (http://creativecommons.org/licenses/by/3.0/). 